\title{
Psalm 44: Die God wat nooit sluimer of slaap nie ... moet wakker word!*
}

L P Maré

(Randse Afrikaanse Universiteit)

\section{ABSTRACT}

\section{Psalm 44: The God who never sleeps nor slumber ... should wake up!}

In Psalm 44, the author accuses Yahweh of sleeping. This is an extremely serious accusation, especially in the light of Psalm 121:4 which explicitly states that Yahweh, in contrast with the gods of the other nations, never sleeps. Why does the author make this accusation? The Psalm begins with Yahweh being praised for showing his goodness in delivering his people and bringing them to the Promised Land. No mention is made of Yahweh sleeping here! It is exactly this contrast between what Yahweh has done in the past and the current situation of his people that results in the accusation against God. The aim of this article is to show that believers today have similar experiences where God acts differently from what is expected of Him and that Psalm 44 should be utilized by the Church to teach its people that, they too, can bring their lament and accusations against God to God, when they feel forsaken by Him.

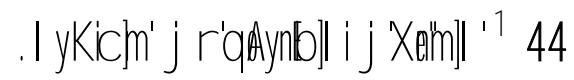

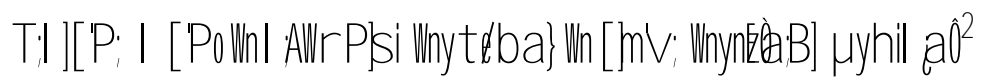
, $\mu d q$, ymeB i $\mu$ h ymeb i

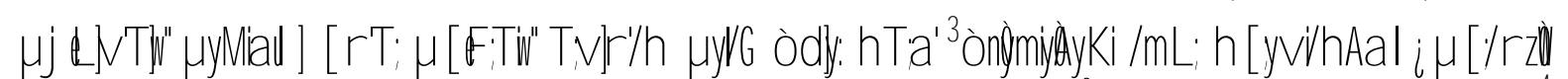
Ar a;W r y: $\mu B r i b] a l i y K i^{4}$

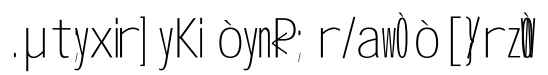

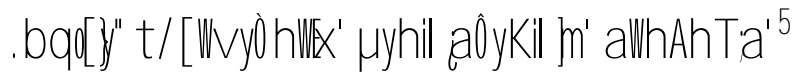

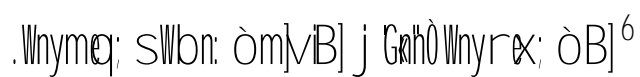

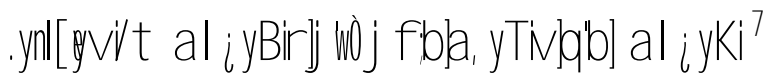

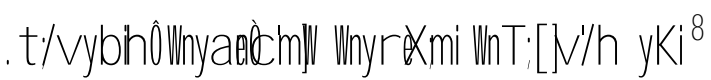

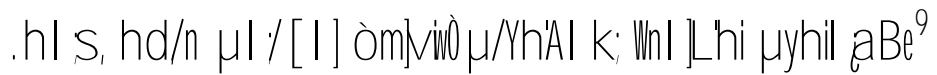

* Hierdie artikel spruit voort uit navorsing wat Maré vir die graad D Litt et Phil aan die RAU gedoen het met Prof Johan Coetzee as promotor. 


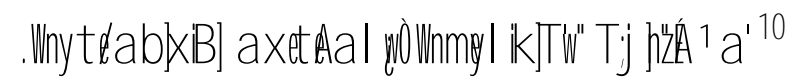

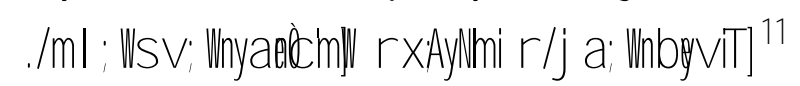

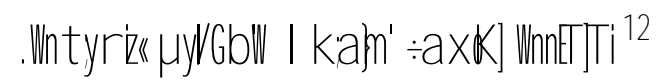

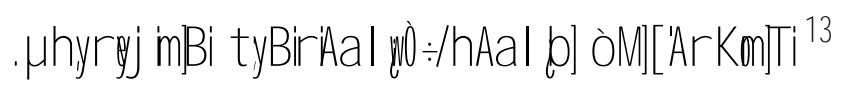

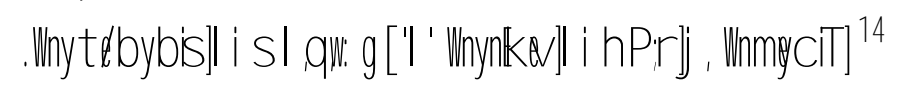

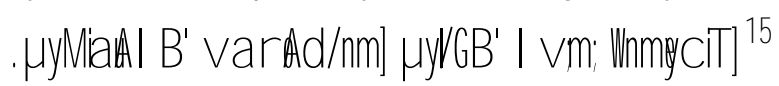

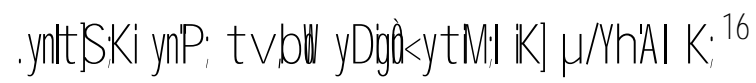

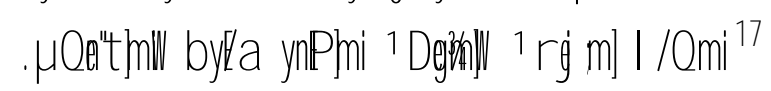

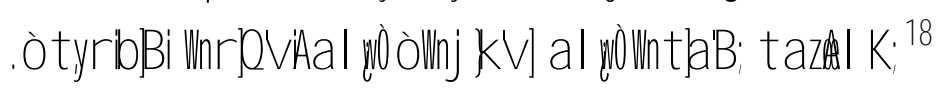

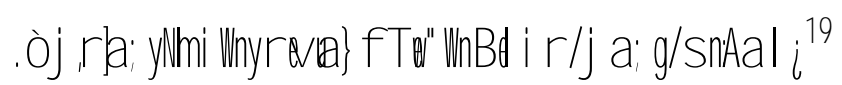

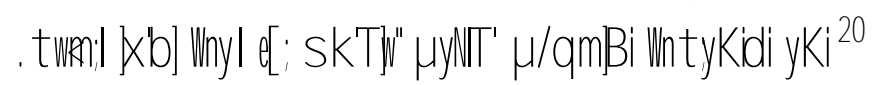

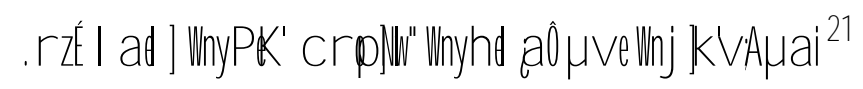

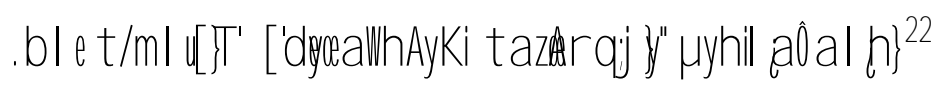

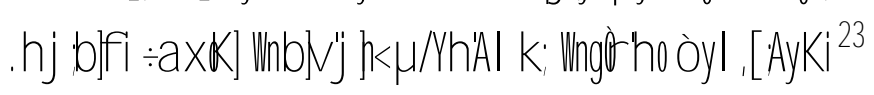

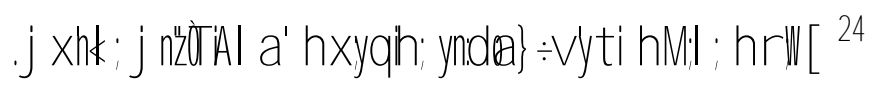

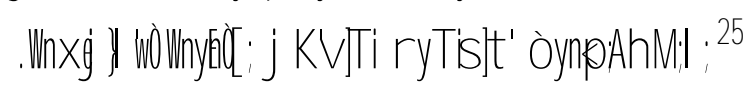

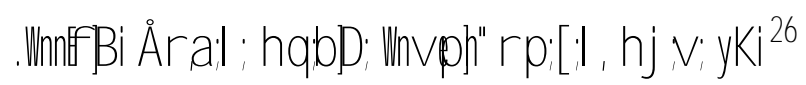

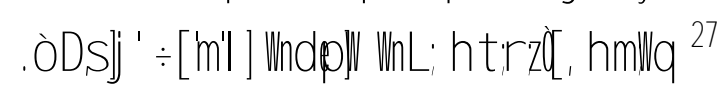

\section{INLEIDING}

Die digter van Psalm 44 rig ' $n$ vreeslike aanklag teen Jahwe: Hy slaap! Die klink byna na lastering dat Jahwe beskuldig word dat Hy slaap. Hy is immers die God wat volgens Psalm 121:4 nooit sluimer of slaap nie. Die heidense gode was wel daarvoor bekend dat hulle soms geslaap het ( $\mathrm{vgl} 1$ Kon 18:27), maar nie Jahwe, die God van Israel nie.

Hoekom maak die digter hierdie beskuldiging? Die psalm begin immers op ' $\mathrm{n}$ vreugdevolle noot in die eerste stanza, waar God aanbid word vir sy wonderwerkende krag wat $\mathrm{Hy}$ in die verlede vertoon het. Dit spreek tog nie van 'n God wat slaap nie. Daarna gaan die digter egter tot klag oor, wat in die beskuldiging teen Jahwe uitmond. Die eerste stanza staan dus in skerp kontras met die res van die psalm. Dit is juis hierdie 
kontras tussen Jahwe se optrede in die verlede en die huidige situasie van die volk, wat die beskuldiging teen Jahwe tot gevolg het.

\section{DIE STRUKTUUR VAN DIE PSALM}

Die struktuur van die psalm vertoon die tipiese elemente van 'n klaaglied. In die eerste stanza (stiges 2-9) staan die reddingsdade van God ter wille van sy volk voorop. Hy het die volke verdryf, die nasies se mag gebreek, aan sy volk 'n vaste woonplek en vryheid gegee. Dit was nie Israel se eie krag wat hulle besit van die land gegee het nie, maar God se krag, mag en teenwoordigheid. Hierdie reddingsdade van God in die verlede vorm die basis vir die digter se vertroue in die hede, wat uitmond in ' $\mathrm{n}$ oproep tot lof.

Stanza 2 (stiges 10-17) bevat die klag van die digter oor God se negatiewe optrede teenoor die volk. Die ervaring van die volk wat heeltemal weerloos staan voor 'n God wat hulle aan hul lot uitgelewer het, word sterk beklemtoon. Dit is eintlik ondenkbaar dat dit God self is wat sy volk verstoot het en hulle in die hande van hulle teëstaanders oorgegee het. Die volk rig hulle klag tot God, weens die feit dat Hy himself in die verlede bewys het as ' $\mathrm{n}$ betroubare God op Wie gehoop kan word en by Wie gekla mag word.

Hierdie klag gaan oor in die volk se aanspraak op onskuld (stanza 3, stiges 18-23). Hulle ontkenning dat hulle verbondsbreuk gepleeg het, staan in skerp kontras met God se negatiewe optrede teenoor hulle. Ten spyte van die feit dat Israel nie ander gode gevolg het nie, ly hulle tog om God se ontwil. Die vierde stanza (stiges 24-27) bevat die petisie van die volk; die smeking om hulp en verlossing uit die huidige noodsituasie.

\section{TRADISIES EN TEMAS IN PSALM 44}

Die digter van Psalm 44 maak van ' $n$ hele aantal tradisies en motiewe gebruik. Die landinnametradisie kom voor in stiges 3-4 (vgl Eks 15:17; Jos $3: 10$; Pss 78:54-55; 80:9-10; 105:44; 111:6; 135:10-12). Die belofte van die land is gegee voordat Israel as volk bestaan het (Von Rad 1962:297). "Israel does not dwell in a land to which the changes and chances of history just happen to have brought it, but in a land destined for it by Yahweh's decision even before there was an Israel" (Zimmerli 1978:65). Uiteindelik word hierdie tradisie, deur die herhaling van die belofte, die Leitmotiv vir die hele Heksateug. Daar kan geen twyfel bestaan dat hierdie tradisie van die vroegste tye deel van Israel se teologiese besinning was 
nie (Von Rad 1962:299). Die land was 'n gawe van God, "always associated with the status of Israel as the 'people of Yahweh', and therefore impossible to esteem too highly" (Zimmerli 1978:65), en die intog was die vervulling van die beloftes van God aan die aardsvaders.

In Psalm 44 skakel hierdie tradisie direk met die huidige noodsituasie van die volk. Dit het ten doel om geloofsvertroue by die volk te wek vir die krisis wat hulle nou in die gesig staar. God het sy volk in die land "geplant". Hy het sy mag en krag bewys deurdat hy die land aan die volk gegee het. Hy was in staat om sy beloftes wat in die oertyd gegee was, tot vervulling te bring. Ten spyte van baie krisisse het hy Homself betroubaar bewys deur sy volk uit slawerny, deur die woestyn, tot in die beloofde land te lei. Hierdie wete van God se betroubare handelinge in die verlede, vorm die basis vir vertroue in die huidige krisis. Israel se geloof het ingehou dat hulle verwag het dat God se magtige verlossingsdade van die verlede in die hede en die toekoms voortgesit sou word (Craigie 1983:333).

Israel het nie die Heilsgeschichte verstaan slegs as die storie van die verlede nie, maar as iets wat die lewe van elke individu direk geraak het (Crow 1992:395-396). "It is logical, therefore, to base hope for oneself on God's actions on the past" (1992:395). Aangesien God in die verlede op ' $n$ bepaalde wyse met sy volk gehandel het, sal Hy dit waarskynlik weer in die hede vir die bidder doen. Die bidder wil God oortuig hoe Hy behoort op te tree deur Hom aan sy optrede in die verlede te herinner (1992:395).

Die heilige oorlogtradisie gaan hier hand aan hand met die landinnametradisie (Coetzee 1986:143; Von Rad 1969:82). Hier is ' $n$ tipiese voorstelling van die heilige oorlogtradisie, waarin God self aktief aan die oorlog deelneem (Hossfeld \& Zenger 1993:275). Die heilige oorlog het nooit " $n$ imperialistiese ekspansionisme ten doel gehad nie, maar "it always secures the rights guaranteed to Israel by Yahweh" (Zimmerli 1978:60). Die heilige oorlog is as Jahwe se oorlog gesien, en die vyande van die volk as Jahwe se vyande (Von Rad 1969:9).

God se aksie en die volk se nie-aksie word hier in Psalm 44 gekontrasteer: dit was nie die volk se arm wat die oorwinning gebring het nie, maar God se regterhand en sy arm (vgl Eks 13:3, 9, 14; Deut 6:21; 11:2; Pss 77:16; 89:11, 14, 22; 98:1). God word as "n krygsman voorgestel wat self vir die behoud en redding van sy volk veg. Hierdie stryd wat God in die verlede ter wille van sy volk gevoer het, vorm die basis vir die geloofsvertroue in die hede. Omdat God in die verlede vir sy volk geveg 
het, kan daar van Hom verwag word om dieselfde in die hede te doen. "Die lig van u aangesig" as beeld van oorwinning kom ook in Psalms 4:7; 31:17 en 89:16 voor (Coetzee 1986:143).

Die tema van God se redding neem 'n prominente plek in die psalm in (vgl Coetzee 1986:143-144). Die psalm word omvou deur hierdie tema deurdat dit daarmee begin (stiges 2-9), en daarmee afsluit (stiges 24-27). Hierdie tema word in stiges 2-9 ten nouste met die landinnametradisie verbind. Dit gaan hier om God se redding in die verlede, wat die basis is vir die oproep dat God sy redding ook in die toekoms sal laat geld (stiges 24-27). Die $d s j$, van Jahwe word voorgehou as die motivering vir die redding vir die toekoms (stige 27; vgl Pss 6:5; 25:7; 107:20; 136; 2 Kron 20:21-22). Jahwe se $d s j$, "refers to acts of love as well as the attribute" (Harris 1980:307). Hier in Psalm 44 is dit " $n$ aanduiding van Jahwe se liefde en getrouheid aan sy verbond met Israel, wat tot uiting kom in sy reddingsdade. Sy liefde vir sy volk gaan oor in aksie. Jahwe se $d s j$, is nie net woorde nie, maar word deur sy reddingsdade bewys.

Israel het geweet dat God ' $\mathrm{n}$ betroubare God is. Hy het Homself in die verlede so bewys, daarom maak hulle ' $n$ beroep op sy verbondstrou en -liefde, om hulle in hul nood te hulp te kom. Dit is vir die volk onverstaanbaar dat Jahwe hulle in die steek gelaat het, ten spyte van die feit dat hulle getrou was aan die verbond (stiges 18-19). Hulle het steeds, gekonfronteer met die oënskynlike teenkanting van God, Hom vasgegryp vir hulle redding. Hulle het teen God, aan God vasgeklou. "Though the covenant ... had become a mystery, still it was only in the covenant lovingkindness of God that there remained any hope of redemption" (Craigie 1983:334).

Die onderrig aangaande die heilstradisies (stige 2), is ' $\mathrm{n}$ welbekende tema in die Ou Testament (vgl Ps 78:3-7; Eks 10:2; 12:26; 13:8,14; Deut 4:9, 6:20, 11:19; J1 1:3). Die nageslag moes onderrig word aangaande die groot dade van God reg deur die geskiedenis van die volk. In Psalm 78:3-7 word dit uitdruklik gestel dat die motief vir hierdie oorvertelling van God se heilsdade daarin lê dat die nageslag nie die groot dade van God moet vergeet nie, en dat dit hulle vertroue in Jahwe sal versterk. Die funksie daarvan is om 'n basis vir vertroue by die volk wat in hulle huidige nood tot God roep, te skep.

' $n$ Verdere tema wat aandag vereis, is dié van God se verstoting en beskaamdmaking van die volk (stiges 10-15). Hierdie tema kom dikwels 
in die psalms voor (vgl Pss 22:2; 39:9; 43:2; 69:10-13; 71:11; 74:1; 79:4; 89:39-46; 108:12; vgl ook Rigt 6:13; Jes $2: 6 ; 49: 14)$. God se verstoting word in Psalm 44 beleef as ' $\mathrm{n}$ neerlaag in oorlog (10-11), verstrooiing onder die nasies (12), (wat moontlik na die ballingskap verwys), verkoping van die volk, sonder dat God enige wins daaruit maak (13), 'n bespotting en ' $n$ spreekwoord onder die ander volke. Dit is as ' $n$ groot bedreiging beskou om tot 'n spreekwoord onder die nasies gemaak te word (stige 15; vg1 Deut 28:37; Jer 24:9; Coetzee 1986:145).

Hierdie tema is die teenpool van die $h \not h y d s j$, , Dit is vir die volk onverklaarbaar dat God, wat "n verbond met hulle gesluit het en Homself in die verlede getrou bewys het aan daardie verbond, nou in die hede teenstrydig optree met die gedagte van getrouheid aan die verbond, en Hy sy volk verstoot sonder enige rede. Die volk is as 't ware besig om God aan te kla van onregverdigheid en onbillikheid teenoor hulle. Hier vind ons ' $n$ voorbeeld van dit wat Brueggemann (1980:12; 1995:19) in navolging van Ricoeur ' $n$ ¿hermeneutiek van suspisie noem. Hierdie aanklag wat teen God gerig word, "is necessary in a situation in which the old worldview, old faith presuppositions, and old language are no longer adequate" (Brueggemann 1995:19). Hierdie aanklag is die ontboeseming van mense wat voel dat hulle deur God verraai en oorgelewer is, van mense wat voel dat alles om hulle duister geword het, en alles waarin hulle geglo het, om hulle ineengestort het. Dit is die woorde van mense wat God byna as hulle vyand ervaar. Goldingay (1978:63) beskryf dit as ¿n "hostility which assails ... most vehemently the person of God". Tog kan hulle nie anders as om hulle op God se $d s j$ te beroep nie. Psalm 44 is uiteindelik nie net ' $n$ verklaring van lojaliteit nie, maar dit is ' $\mathrm{n}$ sterk protes teen God (Broyles 1989:141).

' $\mathrm{n}$ Verdere tema in Psalm 44 is dié van die bedreiging van die vyande. Daar is ' $n$ kontras in die psalm ten opsigte van die wyse waarop die vyande beskryf word. In stige 3 is die vyande die objek van God se optrede: Hy het hulle verdryf en kwaad aangedoen. In stige 6 is dit Israel self wat deur God se werking die vyande tot niet maak en vertrap, terwyl stige 8 die beskaamdmaking van die vyande beskryf. Dit wat hier aan die vyande gedoen word, is ten nouste verbonde aan God se gunstige optrede teenoor sy volk. Omdat God teen Israel se vyande is, word hulle vernietig. Hierdie negatiewe beskrywing van die vyande word aan die landinnametradisie gekoppel, want dit is daar waar God vir sy volk geveg het (stiges $3-4)$. 
Die beskrywing van die vyande verander egter vanaf stige 10 . Die rede hiervoor is in God se veranderde optrede teenoor sy volk geleë. "Each line describes God as taking an active role in Israel's destruction ... God acts unscrupulously (cf v 13), in contradiction to God's normal modus agendi vis-à-vis Israel as portrayed in v. 2-9" (Crow 1992:397). Hy is nou self teen sy volk, daarom triomfeer die vyande. In plaas daarvan dat die vyande tot skande gebring word, is dit nou die volk se lot (stige 14). Die vyande word beskryf as haatdraendes wat plundertogte teen die volk van die Here voer (stige 11). Hulle smaad en belaster die volk (stige 17), as gevolg van die feit dat Jahwe Israel verstoot het.

' $n$ Volgende motief is die bidder se onskuld (stiges 18-23). Hierdie tema kom ook elders in die Psalmbundel voor (vgl Pss 7:4-6; 17:3-4; 26:46; 59:4-5). Hierdie motief funksioneer as 'n skerp kontras met dit wat God aan die volk doen. Hy gee hulle aan hulle vyande oor ten spyte van die feit dat die volk aan die verbond getrou is, en hulle nie agter ander gode aangegaan het nie. Die onskuldmotief is in hierdie psalm ook onlosmaaklik verbind aan die aanklag wat die volk teen God bring. Dit is juis omdat hulle hul onskuld bepleit, dat die optrede van God so onverklaarbaar is, en hulle Hom aankla dat Hy hulle verstoot en oorgelewer het.

Hierdie teenstrydigheid in God se optrede met die bepalings van die verbond, wat die basis vir die volk se onskuldpleidooi vorm, lei tot niks anders as ' $\mathrm{n}$ geloofskrisis nie (Broyles 1989:140). Die psalm bied geen werklike oplossing vir hierdie spanning tussen God se negatiewe optrede en die volk se onskuld nie (Coetzee 1988:5). Die enigste moontlike oplossing word in die woord oyl [; (stige 23) gevind: dit is om God se ontwil dat die volk ly (vgl Ps 69:8; Jer 15:15; Rom 8:36). oyl l ; beteken nie hier dat dit tot Jahwe se voordeel was, dat die volk gely het nie, maar "it was because of their devotion to him ... that they had been defeated and killed" (Bratcher \& Reyburn 1991:417). Die volk het gely omdat hulle Jahwe se besitting was. Hulle was martelaars ter wille van God. Psalm 44 bring die uniekheid van uitverkiesing as God se volk en die misterie van die lyding van die regverdige met mekaar in verband (Kraus 1993:448).

Die psalm beklemtoon egter dat die volk nie hierdie lyding ter wille van Jahwe sondermeer aanvaar nie. Daar is reeds gewys op die aanklag wat die volk teen God bring, al is dit lyding om sy ontwil. Dit getuig van 'n eerlike worsteling van die mens met ' $n$ onverstaanbare God, " $n$ erkenning dat God alleen die oorsaak van die heil en die onheil is wat oor 
die volk kom (Coetzee 1986:147; 1988:5). In stiges 18-23 vind ons uiteindelik ' $n$ teologie wat ooreenstem met dié van Job (Gerstenberger 1988:185; Goldingay 1978:65), waar duidelik aangetoon word dat God groter as die mens se denkskemas oor Hom is. Hy is ' $n$ soewereine God, daarom kan Hy vrymagtig (nie wispelturig nie!) optree.

God se verborgenheid is ' $n$ omvattende tema in die psalm. Hierdie tema funksioneer op twee vlakke in die psalm (Coetzee 1986:148-149). In die eerste plek kom dit na vore deurdat God sy volk se ellende en verdrukking vergeet, dat Hy met ander woorde passief is, en niks doen om hulle lot te verander nie (stige 10 - Hy trek nie uit saam met hulle leërs nie, 24 - Hy slaap, en 25 - Hy vergeet van hulle). Israel teken heftig protes aan teen hierdie "vergeetagtigheid" van God. In stige 24 kom die tweede faset van sy verborgenheid na vore. Hier is God aktief, Hy verstoot sy volk. Hierdie "aktiewe verborgenheid" blyk ook uit stiges 10-23. Die volk ervaar beide fasette van God se verborgenheid, wat lei tot intensivering van hulle nood.

Die tema van lofprysing aan God kom voor in stige 9. Die lof wat aan God gebring word, spruit voort uit sy reddingsdade. Jahwe word geloof, omdat Hy Homself in die geskiedenis betroubaar bewys het deur reddend op te tree vir sy volk en teen die vyande van die volk. Die tema hou dus direkte verband met sowel die tema van redding as die landinnametradisie.

Olivier en Swanepoel (1997:207) meen dat die verwysing na God se reddingsdade in die verlede nie as motief vir lof beskou moet word nie, maar slegs om die kontras tussen die verlede en die hede op die spits te dryf. Myns insiens sluit die twee gedagtes mekaar nie uit nie. Dit is wel so dat die kontras tussen God se optrede in die verlede en die huidige nood van die volk in skerp kleure geteken word, maar dit neem nog nie die feit weg dat daar lof aan God gebring word vir sy reddingsdade in die verlede nie. Dit is juis die feit dat God se aktiwiteite in die verlede lofwaardig is wat die kontras met die huidige ellende van die volk soveel intenser maak.

Die tema van God se verbond met Israel kom in stige 18 voor. Dit hang hier met die onskuldstema saam. Israel maak daarop aanspraak dat hulle nie van die verbond wat God met hulle gesluit het, afgewyk het nie. Die verbond verwys hier na die verbond wat God by Sinaï met die volk gesluit het. Volgens Deuteronomium 28 kon Israel verwag dat hulle getrouheid aan die verbond gevolg sou word deur die seën van die Here, 
en ontrouheid deur vervloekinge. Die teenoorgestelde het egter gebeur. Hulle getrouheid het vir hulle negatiewe gevolge ingehou. Dit is hierdie verwagting van seën as gevolg van hulle gehoorsaamheid aan die bepalings van die verbond wat Israel se dilemma veroorsaak. Hulle het hulle kant van die ooreenkoms nagekom, maar God het nie. Tog kan hulle nie anders as om ' $n$ beroep op Jahwe se verbondstrou en liefde te maak nie, sodat Hy hulle sal verlos (stige 27).

Die tema van God se alwetenheid kom in stige 22 voor. Hierdie attribuut van God word op ' $n$ treffende wyse in Psalm 139 aan die orde gebring. God ken die mens in die fynste besonderhede van sy wese. Die rede vir God se alwetenheid hang saam met die feit dat Hy Skepper is (vgl Ps 139:13, 15, 16; Job 28:20-27). God ken die wêreld en die mens omdat Hy dit gevorm het, dit is die werk van sy hande. Hier in Psalm 44 hang hierdie tema met die onskuldstema saam. Omdat God alwetend is, sou Hy geweet het indien Israel van Hom afgedwaal het agter ander gode aan om dié te aanbid. Hulle het dit nie gedoen nie. God behoort dit te geweet het. Dit vererger Israel se geloofskrisis, want dit lyk asof God teenstrydig met sy eie karakter optree.

' $n$ Laaste tema wat in Psalm 44 ter sprake is, is in stige 24 te vinde: God wat slaap. Die psalmdigter plaas God hier in dieselfde kategorie as gode soos Baäl, wie se profete deur Elia by Berg Karmel gespot is, dat hulle god slaap (1 Kon 18:27). Tog is Jahwe die God van wie in Psalm 121:4 gesê word dat Hy nooit sluimer of slaap nie. Hier vind ons 'n treffende voorbeeld van dit wat Brueggemann (1997:317) Israel se kruisverhoor van Jahwe noem. Israel se getuienis aangaande Jahwe is dat Hy nooit sluimer of slaap nie (Ps 121:4). Hulle neem Hom egter onder kruisverhoor, omdat hulle ervaring in hierdie situasie daarvan spreek dat Hy miskien tog aan die slaap geraak het. Dit hef nie hulle getuienis van sy nie-slaap op nie. Hulle kruisverhoor spruit egter voort uit hulle konkrete lewenservaring omdat Jahwe volgens hierdie ervaring anders optree as wat hulle in lyn met hulle getuienis aangaande Hom sou verwag (vgl Brueggemann 1997:318).

Die digter word hier gekonfronteer met 'n verskriklike ervaring: God se stilswye. Die vraag waarom God slaap is nie " $n$ versoek om informasie nie, maar dit is ' $n$ retoriese vraag wat Jahwe beskuldig dat Hy anders optree as wat Hy behoort op te tree. Die vrae na Jahwe se slaap is "a desperate cry born from deepest despair and bewilderment ... they are 
bitter complaints against God's apparent indifference to and neglect of his people as they suffer and die" (Bratcher \& Reyburn 1991:418).

Dit is inderdaad baie sterk taal om teenoor God te besig, maar dit gee uiteindelik uitdrukking aan die desperaatheid van mense wat God as afwesig in hulle lewens ervaar. Die wonder van hierdie taalgebruik is juis daarin geleë dat God toelaat dat desperate mense so met Hom praat. Hy aanvaar dit omdat dit uitdrukking gee aan die diepste emosies en gevoelens in die hart van sy volk wat eerlik met Hom worstel in tye van geloofskrisis. Hierdie psalm appelleer tot God teen God (Olivier \& Swanepoel 1997:212). Hy word verantwoordelik gehou vir die krisis wat die volk beleef, maar Hy is ook die enigste een wat die situasie kan omkeer en nuwe lewe kan skenk.

\section{SAMEVATTING EN SLOT}

Psalm 44 spreek van die wisselende emosies wat die mens dikwels ervaar wanneer hy voor God in aanbidding kom. Hierdie wisseling van emosies is reeds in die breë struktuur van die psalm sigbaar. Die eerste stanza (2-9) staan in skerp kontras met die res van die psalm. Die psalm begin op ' $n$ vreugdevolle toon, waar God aanbid word vir sy wonderwerkende krag wat hy in die verlede betoon het. Die digter gebruik die landinname- en heilige oorlogtradisie om die verlede in herinnering te roep en te wys op God se wonderwerkende krag in die geskiedenis van die volk. Daardeur besing die digter die lof van God en skep hy 'n basis vir vertroue in Jahwe by die volk vir die hede en die toekoms.

Jahwe word aanbid omdat Hy konkreet in die geskiedenis van die volk, op die oorlogsveld, sy almag ten gunste van sy volk laat geld het. Die verlede getuig vir die volk van God se werk, want dit is deur sy krag en nie die mens se vermoëns nie, wat die oorwinning behaal is. Hierdie twee tradisies verkry ' $n$ evangeliese funksie in die psalm deurdat dit aan die daaropvolgende geslagte van God se verlossingsdade getuienis dra.

Hierdie positiewe noot waarmee die psalm begin, is egter misleidend. " ... it merely sets the stage for the terrible lament which is to follow" (Craigie 1983:333). Hierdie wisseling tussen positief en negatief is kenmerkend van die ervarings van die lewe. Alle mense beleef hierdie emosies. Die geheim bly, soos die digter van hierdie psalm gedoen het, om beide positief en negatief in aanbidding voor God te bring. Pleins (1993:40) skryf tereg: "The brutality of the world does not permit us to assume that worship will always be easy or soothing". Aanbidding bestaan 
nie net uit uitinge van lof en blydskap nie. Dit omsluit die totale lewenswêreld van die mens. Pleins (1993:37) is daarom heeltemal in die kol wanneer hy skryf: "When the community suffered terrible devastation because of foreign intervention, it became the task of worship to speak to God out of the horrors of war".

Die positiewe, vreugdevolle noot waarmee die psalm begin, moet deel wees van die kerk se aanbiddingslewe. Soos Israel in Psalm 44 terugkyk oor haar glorieryke verlede en hulle die groot dade van God in herinnering roep, kan die kerk vandag ook ' $n$ terugblik gee oor dit wat verby is en God vir sy grootheid en almag loof.

Dit is egter so dat Christene vandag dikwels ' $n$ kontras beleef tussen dit wat God in die verlede gedoen het, en die situasie wat in die hede geldig is. Dit was die ervaring van Israel in Psalm 44 waar "... a glorious past of a life with God is inexplicably reversed into a miserable present without Him. His former deliverance is substituted by his hiddenness; his activity by inactivity; his nearness by absence and ultimately, his faithfulness by betrayal" (Human 1998:582).

Die kerk word vandag ook soms met ' $n$ vrymagtige God gekonfronteer wat anders optree as wat van Hom verwag word. Die digter benut ' $n$ hele aantal temas om hierdie vreemdheid van God se optrede te beklemtoon. Israel het ondervind hoe God hulle verstoot en hulle tot ' $n$ bespotting gemaak word. God verberg sy aangesig vir hulle; Hy slaap selfs. Israel ervaar dat hulle uitverkoop is aan hulle vyande sonder dat God enige voordeel daaruit getrek het. Hierdie verwerping van die volk sou nog verstaanbaar wees indien hulle die wet oortree het en hulle van die verbond afgewyk het. Deuteronomium 28:15-68 is die klassieke voorbeeld van die lot wat die volk sou tref indien hulle van die bepalings van die verbond sou afwyk. Israel bepleit egter hulle onskuld. Hulle het nie oortree nie; dit is juis hierdie feit wat God se optrede so onverstaanbaar maak.

Israel moes ' $n$ verandering in hulle teologiese denke gemaak het. Die kerk sal ook so ' $n$ verandering in hulle denke oor God moet maak. Vir baie Christene, veral diegene wat voorstaanders van die voorspoedsteologie is, is die gedagte wat Psalm 44 hier uitspreek absoluut onaanvaarbaar. Volgens hierdie denkrigting tree God altyd in gebondenheid aan sy Woord op. Dit sou beteken dat God Israel nie sou verstoot het nie indien die volk wel aan die verbond getrou was in ooreenstemming met Deuteronomium 28. Die logiese gevolgtrekking wat mens dan moet maak, is dat Israel nie 
die waarheid praat wanneer hulle hulle onskuld bepleit nie. Indien hulle onskuldig was, sou dit met hulle steeds goedgegaan het, en nie sleg nie.

Hierdie soort teologie plaas God in 'n bepaalde skema waar Hy nie buite die grense van daardie (menslike) skema kan beweeg nie. Dit is baie duidelik ' $n$ beperking van die soewereiniteit van God. God is egter verhewe bo enige menslike skema of denkpatroon, en Hy kan maak soos wat Hy wil. Hy kan nie in die denkskemas van sy kerk vasgevang word nie.

Die kerk moet vandag besef dat God soms anders optree as wat die mens se teologiese denke oor Hom voorsiening maak. Die feit van die saak is dat baie Christene in hulle daaglikse lewenswandel te make het met die vreemdheid van ' $n$ onverstaanbare, stilswyende God. Christene ly vandag dikwels onskuldig. Hoe dit deur die kerk hanteer moet word, is die crux van die saak. 'n Goedkoop teologie, wat maklike antwoorde probeer gee, is nie die antwoord om die mens in sy nood te onderskraag nie. Die antwoord is daarin geleë dat die Christen in 'n eerlike worsteling met God betrokke moet raak, dat hy selfs die vuis beskuldigend vir God kan bal, en sy klag teen God, tot God rig.

Net soos Israel moes leer dat hulle soms ly ò l [ ; moet die kerk leer dat hulle lyding ook ter wille van God kan wees, sonder ' $n$ verklaarbare rede. Die Nuwe Testament leer presies dieselfde (vgl Rom 8:36; Fil 3:10 waar Paulus die begeerte uitspreek dat hy aan Christus se lyding deel wil hê). Lyding ter wille van God is ' $\mathrm{n}$ tema wat regdeur die Bybel voorkom. Die gelowige word trouens opgeroep om deel te hê aan Christus se lyding (1 Pet 2:21). Dit beteken nie dat die Christen dit in stilswye hoef te aanvaar nie, maar hy mag dit deur sy klag met God opneem.

Israel het God beleef as ' $n$ stilswyende God wat hier optree soos wat die heidense afgode gemaak het. Tog is Hy nie dieselfde as daardie stom afgode nie. Die taalgebruik is inderdaad sterk, en dit mag vir baie Christene onaanvaarbaar voorkom om God op hierdie wyse aan te spreek deur vir Hom te sê om wakker te word (vgl bv Oesterly 1962:248 wat dit as "the height of irreverance" beskou), maar die feit van die saak is dat God die gelowige die reg gee om op so " $n$ dringende wyse met Hom te praat. Leupold (1969:350) noem dit tereg "the boldness of faith". Dit spreek immers van die mens wat in die verskrikking van sy nood, en met die besef van sy geloof/ongeloof, tot die wete kom dat God, alhoewel Hy vreemd optree, nog steeds sy enigste hoop en toevlug is. 
Om God te beskuldig van ontrouheid mag vreemd en onaanvaarbaar voorkom, maar die feit bly staan dat Christene se ervarings van die lewe hulle dikwels op die plek bring waar hulle vir God kwaad is. Die onverklaarbare dood van ' $\mathrm{n}$ geliefde bring byvoorbeeld sodanige emosies sterk op die voorgrond. God weet (Hy is alwetend) van daardie emosies en gevoelens. Verwoording daarvan bring die mens nie net op ' $n$ plek van volkome eerlikheid voor God nie, maar ook op 'n plek waar sy helende krag stukkende emosies en harte kan genees en herstel.

Net soos Israel ' $n$ beroep gedoen het op die hwhy $d s j$, kan die kerk vandag dieselfde beroep maak op God se liefde in Christus Jesus. Die hesed Jahwe (hwy $d s j$ ) is die finale basis vir die hoop en die vertroue wat die mens kan hê dat God in sy nood sal ingryp, al wil dit voorkom asof God sy rug op die mens in sy nood gedraai het.

Christene kan, nee, moet Psalm 44 in hulle aanbiddingstaal insluit. Is dit nie " $n$ gebrek in die aanbiddingslewe van die kerk vandag dat daar nie plek is in ons himnodie om die angs en vertwyfeling en vrees wat mense vandag in ons eie land beleef as gevolg van die geweldige misdaad, te verwoord nie? Die kerk sal altyd die verantwoordelikheid hê om God se lof te besing, soos Psalm 44 ook leer. Die kerk het egter net so ' $\mathrm{n}$ groot verantwoordelikheid om te midde van die gebrokenheid van die wêreld, waar die mens soms ook van God verlate voel, gelowiges te leer om ook hulle klag, hulle beskuldiging, na God te neem.

\section{Literatuurverwysings}

Bratcher, R G \& Reyburn, W D 1991. A translator's handbook on the book of Psalms. New York: United Bible Societies.

Broyles, C C 1989. The conflict of faith and experience in the psalms: A form-critical study. Sheffield: Sheffield Academic Press (JSOT Supplement Series 52).

Brueggemann, W 1980. Psalms and the life of faith: A suggested typology of function. JSOT 17, 3-32.

-, 1995. The Psalms and the life of faith, ed by P D Miller. Minneapolis: Fortress.

-, 1997. Theology of the Old Testament: testimony, dispute, advocacy. Minneapolis: Fortress.

Coetzee, J H 1986. Die spanning tussen God se "verborge wees" en sy "ingrype om te red". "n Eksegetiese ondersoek na 'n aantal klaagpsalms. DD proefskrif, Universiteit van Pretoria.

-, 1988. Lyding "om U ontwil” in Psalms 44 en 69. Skrif en Kerk 9(1), 1-9. 
Craigie, P C 1983. Psalms 1-50. Waco: Word (WBC 19).

Crow, L D 1992. The rhetoric of Psalms 44. ZAW 104 (3), 394-401.

Gerstenberger, E S 1988. Psalms: Part 1 with an introduction to cultic poetry. Grand Rapids: Eerdmans (FOTL 14).

Goldingay, 1978. Songs from a strange land: Psalms 42-51. Leicester: Inter-Varsity (The Bible speaks today).

Harris, R L 1980. ds j 。 in Harris, R L, Archer, G L \& Waltke, B K (eds), Theological Wordbook of the Old Testament, 2 volumes. Chicago: Moody Press.

Hossfeld, F-L \& Zenger, E 1993. Die Psalmen I: Psalm 1-50. Würzburg: Echter (NEB).

Human, D J 1998. Psalm 44: "Why do you hide your face?" How contrast contributes to the psalm's understanding. Skrif en Kerk 19(3), 566-583.

Kraus, H-J 1993. Psalms 1-59, tr by H C Oswald. Minneapolis: Fortress.

Leupold, H C 1969. Exposition of Psalms. Grand Rapids: Baker Book House.

Oesterley, W O E 1962. The Psalms. London: SPCK.

Olivier, H \& Swanepoel, P 1997. Eerlik met God in die krisisuur: 'n Bespreking van die aard van die klaagpsalms. In die Skriflig 31 (3), 199-214.

Pleins, J D 1993. The Psalms: songs of tradegy, hope and justice. Maryknoll, NY: Orbis.

Von Rad, G 1962. Old Testament Theology Volume 1, tr by D M G Stalker. Edinburgh: Oliver \& Boyd.

Von Rad, $\mathrm{G}^{5}$ 1969. Der Heilige Krieg im alten Israel. Göttingen: Vandenhoeck \& Ruprecht.

Zimmerli, W 1978. Old Testament Theology in outline, tr by D E Green. Edinburgh: T \& T Clark. 